\title{
EARLY WARNING SYSTEM IN MANAGING WATER INFRASTRUCTRE PROJECTS
}

\author{
Mariela SJEKAVICA KLEPO ${ }^{*}$, Mladen RADUJKOVIĆ(1D2, 3 \\ ${ }^{1}$ Croatian Water, Zagreb, Croatia \\ ${ }^{2}$ Faculty of Civil Engineering, University of Zagreb, Zagreb, Croatia \\ ${ }^{3}$ Alma Mater Europea ECM, Maribor, Slovenia
}

Received 28 November 2018; accepted 03 April 2019

\begin{abstract}
There is a continuous need to improve existing project management decision-making support models, particularly those for monitoring and control are needed to increase chances for success. In this paper, potential of early warning in project management was focused, along with its connection to project success via project success factors. First, a systematic literature review was conducted, along with the focus group method, in order to identify project success factors. The selected success factors were also collected on 93 water infrastructure projects through a survey. By the means of linear regression analysis, critical success factors were finally determined. The results were integrated in the early warning system algorithm, composed by three modules - detection, validation and response module. The response module is composed by three dimensions: 1) risk, constraint and change management, 2) incorporation of project management competences and 3) application of project management methods, tools and techniques. The proposed early warning system was tested on three infrastructure projects. The results confirmed that improved early warning system can contribute in increase of project management success. As original database is composed by projects from only one country (Croatia), in the final stage of the research proposed approach was checked in five countries from the Central or South East Europe (Czech Republic, Slovenia, Serbia, North Macedonia, Bosnia and Herzegovina). The results from the final stage confirmed potential of the proposed approach as declared originally, so it is reasonable to expect success in early warning system's implementation due to similarities of critical success factors on projects as well as project management problems in general, that countries in regions share. This research presents new and creative way in linking early warning and project success, as well as interpretation of early response through different dimensions in project management. Also, based on the results of this research, it is possible to create a useful practical tool for managing other types of projects.
\end{abstract}

Keywords: early warning system, infrastructure projects, project success factors, project management success, linear regression analysis, risk, change, constraint, competence, tools.

\section{Introduction}

We live in a world of projects - they are holders of change. Worldwide, capital project and infrastructure spending are expected to total more than $\$ 9$ trillion by 2025 , up from $\$ 4$ trillion in 2012 (PricewaterhouseCoopers, 2014). Already in $2012,97 \%$ of organizations believed that project management is a critical activity for business and organizational success (PricewaterhouseCoopers, 2012). International research about projectification in Germany, Norway and Iceland confirmed 30-35\% share of project work in the economy (Schoper, Wald, Thor Ingason, \& Vikingur Fridgeirsson, 2018). It can be stated that project success and effective project management may be one of the main keys of business and society development in general. The ability to complete projects successfully is of fundamental importance and care within the architecture, engineering, construction (AEC) industry (Molenaar, Javernick-Will, Bastias, Wardwell, \& Saller, 2013) on a special way, because the success of construction projects is a fundamental issue for most governments, users and communities (Gudiene, Banaitis, Podvezko, \& Banaitiene, 2014). Project success as such has many practical and scientific implications, as well as a lot of challenges to face. For every US\$ 1 billion invested in projects, US\$122 million are wasted due to poor project performance (Project Management Institute, 2016). Less than one third of all projects are finished on time and within the budget (Standish Group, 2013).

${ }^{\star}$ Corresponding author. E-mail: mariela.sjekavica@gmail.com 
From the research point of view, many scientists have spent years in trying to define project success and to assess it meaningfully (Mir \& Pinnington, 2014), but without reaching consensus definition of project success (Pinto \& Slevin, 1988, 1992; Baccarini, 1999; Ika, 2009; McLeod, Doolin, \& MacDonell, 2012), which could orient profession to better project management.

Hence, there is a large area of possible contribution in aspiration to enhance chances of successful project management, both in theory and praxes.

In order to do so, a potential of early warning in project management was used in this study. Namely, extremely little literature is dealing with early warning on projects on explicit (Nikander, 2002) and direct (Haji-Kazemi, Andersen, \& Krane, 2013; Haji-Kazemi, Andersen, and Klakegg, 2015) manner, especially in construction (Navon \& Kolton, 2006). On the other hand, the effectiveness of project control lies in the capability of project manager to make his or her decisions early enough (Kim, 2007), before project becomes unsuccessful (Haji-Kazemi et al., 2013). In today's world of project requirements that become more and more complex, there is a need for project managers to forecast future on more effective way, that is - to have more proactive tools (Nikander, 2002) - to help them make good decisions (Haji-Kazemi et al., 2013), and to make project success more likely (Kappelman, McKeeman, \& Zhang, 2007; Vanhoucke, 2012). Therefore, early warning concept has a potential in offering new possible solutions to existing project management problems.

The way that the potential of early warning in project management was used in this study is based on the connection between the concept of early warning and project success via project success factors. Project success factors are elements which, if present, direct project towards success (Cooke-Davies, 2002) and enhance the probability of success (Lim \& Mohamed, 1999; Muller \& Turner, 2007; Jari \& Bhangale, 2013; Gunathilaka, Tuuli, \& Dainty, 2013). Therefore, the absence or low level of presence of project success factors can be indication of a problem, that is - early warning sign. This logic is also shown in Austin (2004), who stated that the concept of early warning and their importance are actually success indicators. Also, capability to identify critical success factors early enough in construction project can enable formation of effective strategy for conflict avoidance and project improvement (Molenaar et al., 2013).

Based on these findings, a main research question is set: is it possible to increase chances for successful management of construction projects by the creation and usage of early warning system based on project success factors?

The aim of this study is to contribute to development of early warning systems based on indicators of construction projects' success, which use will improve present solutions in project management, increase the quality of project monitoring and control and enhance chances of project and project management success.

In order to make the contribution, it is important to state that construction projects are very various, and that one size does not fit all (Shenhar, 2001). Nevertheless, to improve the present state, it is necessary to think outside the framework of particular project uniqueness. In order to show the results of influence of early warning systems' usage on project management success, the study was conducted on one group of construction infrastructure projects: water projects. But, the same methodology and analogous approach may be adapted for different kind of construction projects, or even wider or general, in different sectors. Water infrastructure projects were selected because they are the one of the most important on a strategic level (local, state or European Union, etc.), in a sense of contribution to better living standard of end users. In addition, these financially, time-consuming and technically complex projects are shown to be one of the most challenging in a sense of their management through praxes. The importance of water and sewage systems as well as wastewater treatment plants construction and reconstruction are highlighted through European Union Directives as well as national law and global trends in many countries worldwide. However, the authors believe that the same step-by-step methodology of early warning system's creation can be analogously implemented on other types of construction project, which could be one of directions for the further research.

The research methodology applied is explained below, followed by the structure of the article. The methodology consisted of qualitative and quantitative methods - qualitative part of the study was made based on guidelines of Leavy (2014) and quantitative part was based on Montgomery and Runger (2014).

First, a desk research was made in order to detect early warning systems being in use on direct or indirect manner in project management, as well as to find out which elements are these systems consisted of. Then, a qualitative idea of early warning system was developed, as well as the according algorithm. The results of desk research and presentation of the algorithm's logic is given in the first part of the study, named "Early warning systems".

Then, a systematic literature review was made in order to define project success factors. Based on calculated frequencies of appearance throughout the literature, and application of Pareto principal, a prelaminar base of the possible critical factors was made.

By the means of focus group, this base was revised. Also, focus group added the missing project management competences and project management tool, technique or method, which they considered the most helpful, in the case of absence of revised factors on projects. The competences were based on International Competence Baseline ${ }^{-}$ (International Project Management Association, 2006), and the list of tools, techniques and methods of project management was based on the relevant literature review on the field.

Results of this stage of study are given in the second part of the article - "Project success factors". Afterwards, a data representing the presence of the selected factors on projects of different success was collected through the 
survey. Total number of 31 experienced project managers responded on the survey. Each of them gave answers for three of own projects - one perceived successful, one unsuccessful, and one mid successful. Also, project managers characterized the absence of project success factors on their projects as risk, constraint or change. Consequently, a database for 93 projects was made.

Then, a linear regression analysis was applied, in order to find out the connection between project success factors' presence and project success. Further, to detect groups of factors affecting the critical ones, a stepwise method was used. The statistical analysis was conducted in the software IBM $^{\circledast}$ SPSS $^{\circledast}$ Statistics (International Business Machines Corp., 2012).

Details on survey and results of statistical analysis are given in the third part of the article. Based on the results given, an early warning systems' algorithm was transformed in a user-friendly interface. Created system was tested on real projects. Three project managers expressed their feedback via survey. Results of testing are shown in the fourth part - "Early warning system testing".

Then, a final step of the research was made, in order to examine a possibility of proposed early warning system implementation within a larger regional context (Central and South East Europe). Methodology used in this part of a research, as well its results are given in the fifth part "Early warning system in regional context".

Finally, in accordance to previous research, and main findings of the study, a discussion is drawn. At the end, limitations, recommendations and the final conclusions are given.

\section{Early warning systems}

Early warning system (EWS) is defined as any initiative that focuses on systematic data collection, analysis and/ or formulation of recommendations, including risk assessment and information sharing, regardless of topic, whether they are quantitative, qualitative or a blend of both (Austin, 2004). Igor Ansoff $(1975,1984)$ was the first one to introduce early warning through his theory of weak and, afterwards, strong signals. He claimed that strategic surprises in business do not come out of nowhere; rather, they can be anticipated and acted upon.

The signs that indicate such anticipation are called early warning signs. Systems based on their identification, analysis and acting upon, are, consequently, named early warning systems.

EWS soon became popular in military, economy, IT industry, medicine, crisis and security management, communications, ethno politics and different parts of company strategic management, with the last one being found among construction companies also (Kapliński, 2008). Nevertheless, they stayed outside of focus of project management theory and practice, while only being mentioned indirectly in project management, as it was stated in the Introduction (Nikander, 2002; Haji-Kazemi et al., 2013, 2015). Philip, Schwabe, and Wende (2010) stated that only three major empirical works had studied the concept of early warning in project management: two of which in IT industry (Kappelman et al., 2007; Havelka \& Rajkumar, 2006 according to Philip et al., 2010) and one in construction industry (Nikander \& Eloranta, 2001; according to Philip et al., 2010). On the other hand, Nikander (2002) showed that Ansoff's idea on the usage of weak signals can be used on projects, so it is reasonable to expect possibility of success in development of the corresponding systematic solution for project managers.

In their research, Haji-Kazemi et al. (2015) gave early warning identification sources in project management, while grouping them on direct and indirect sources (Table 1). Except from their research, Table 1 also represents a list of other project tools and systems that anticipate early warning concept in their logic.

What can be seen out of Table 1 is that there are many different, theoretical models and practical tools, which can be put under the early warning category. But, none of them present a complete solution applicable on overall construction project - early warning in shown systems and tools refers mostly only to one of project aspects (e.g. costs, time, safety on construction site, stakeholders), while neglecting other aspects - both of project and project's narrower and wider environment. But, the most frequently methods used in managing projects, such as methods of cost and time control, do not give an effective tool in turbulent project environments, where unexpected changes can happen (Nikander, 2002). In this sense, the most complete solution is one of Vondruska (2014); however, it is related only to early warning identification, and does not attach early warning with project success. Also, its usage is not confirmed with implementation.

The results of desk research make the research niche of this study confirmed - connecting early warning to project success may be one of the possible solutions in creating more effective project management. The logic behind this idea is explained on Figure 1.

Figure 1 presents the concept of making decisions based on early warning signs - which means prevention before problems occur, rather than remediation of problems' consequences once they occur. In the sense of early warning in project management, the ultimate problem can be defined as overrun that can lead to project failure.

So, detecting indicators of possible project failure can be defined as an early warning. Building up a system based on those indicators can be of a great help in avoiding failures of projects and achieving success. But which indicators could be appropriate ones for explained roles?

To answer this question, authors analysed possible indicators of project success. Literature on project success defines two basic success components: project success criteria and project success factors (Bannerman, 2008). Project success criteria are elements/measures due to which project is evaluated as successful or unsuccessful (CookeDavies, 2002; Bannerman, 2008). They depend on the type of project investment (private or public) and can range from the iron triangle criteria of cost, time and quality, all 
Table 1. Early warning systems or tools in project management

\begin{tabular}{|c|c|c|c|}
\hline \multicolumn{2}{|c|}{ Author, year } & \multicolumn{2}{|l|}{ Early warning system or tool } \\
\hline \multicolumn{2}{|l|}{ Pinto and Slevin (1992) } & \multicolumn{2}{|l|}{ Project Implementation Profile } \\
\hline \multicolumn{2}{|l|}{ Fleming and Koppelman (1998) } & \multicolumn{2}{|l|}{ CAP - Control account plan } \\
\hline \multicolumn{2}{|c|}{ Mavrotas, Caloghirou, and Koune (2005) } & \multicolumn{2}{|l|}{ S curves } \\
\hline \multicolumn{2}{|c|}{$\begin{array}{l}\text { Spjelkavik, Andersen, Onsoyen, Fagerhaug, and Marheim } \\
(2008)\end{array}$} & \multicolumn{2}{|l|}{ Project health check tool } \\
\hline \multicolumn{2}{|c|}{$\begin{array}{l}\text { Williams, Klakegg, Walker, Andersen, and Magnussen } \\
\text { (2012) }\end{array}$} & \multicolumn{2}{|l|}{$\begin{array}{l}\text { Project assessment methods } \\
\text { Phase-door models }\end{array}$} \\
\hline \multicolumn{2}{|c|}{ K. Wang, Zhang, X. Wang, and Yu (2009) } & \multicolumn{2}{|c|}{$\begin{array}{l}\text { Early warning system related to safety in mountain highway } \\
\text { construction }\end{array}$} \\
\hline \multicolumn{2}{|c|}{ Abdul-Rahman, Wang, and Muhammad (2011) } & \multicolumn{2}{|l|}{ Earned value analysis } \\
\hline \multicolumn{2}{|c|}{ H. S. Lee, K. P. Lee, Park, Baek, and S. Lee (2011) } & \multicolumn{2}{|c|}{$\begin{array}{l}\text { Real-time location-based construction labour safety management } \\
\text { system }\end{array}$} \\
\hline \multicolumn{2}{|c|}{ Azeem, Hosny, and Ibrahim (2014) } & \multicolumn{2}{|c|}{$\begin{array}{l}\text { Deterministic models of time forecasting on construction projects: } \\
\text { EV (Earned Value); ES (Earned Schedule) } \\
\text { Probabilistic models of time forecast on construction projects: } \\
\text { KFFM (Kalman Filter Forecasting Model) }\end{array}$} \\
\hline \multicolumn{2}{|l|}{ Vondruska (2014) } & \multicolumn{2}{|c|}{ Early warning system in detection of construction projects crises } \\
\hline \multicolumn{2}{|l|}{ Skibniewski (2014) } & \multicolumn{2}{|l|}{ IT applications for construction safety } \\
\hline \multicolumn{2}{|l|}{ Lowe (2016) } & \multicolumn{2}{|l|}{$\begin{array}{l}\text { Maturity models } \\
\text { DICE (Boston Consulting group) } \\
\text { Stakeholder analysis } \\
\text { Simple questions and surveys } \\
\text { Retrospective and lessons learned } \\
\text { Causes and effects diagrams } \\
\text { Burn down charts } \\
\text { Earned value management } \\
\text { Critical path method planning }\end{array}$} \\
\hline \multicolumn{4}{|c|}{ Early warning systems or tools in project management (based on Haji-Kazemi et al., 2015) } \\
\hline \multicolumn{2}{|c|}{ Early warning sources directly discussed in the literature } & \multicolumn{2}{|c|}{ Potential early warning sources indirectly discussed in the literature } \\
\hline Author, year & Source & Author, year & Source \\
\hline Niwa (1989), Nikander (2002) & Risk analysis & $\begin{array}{l}\text { Cleland (1986), Savage, Nix, Whitehead, and } \\
\text { Blair (1991) }\end{array}$ & $\begin{array}{l}\text { Stakeholder } \\
\text { analysis }\end{array}$ \\
\hline $\begin{array}{l}\text { Cooper, Edgett, and } \\
\text { Kleinschmidt (1997), Miller } \\
\text { and Lessard (2000), Wateridge } \\
\text { (2002), Cooper (2005), Jaafari } \\
\text { (2007), } \\
\text { Klakegg, Andersen, Walker, } \\
\text { and Magnussen (2010) }\end{array}$ & $\begin{array}{l}\text { Project assessment } \\
\text { methods }\end{array}$ & $\begin{array}{l}\text { Leszak, Perry, and Stoll (2000), Parker and } \\
\text { Skitmore (2005), Sambasivan and Soon (2007), } \\
\text { Ohatka and Fukazaw (2009), Klakegg et al. } \\
(2010)\end{array}$ & $\begin{array}{l}\text { Cause/effect } \\
\text { analysis }\end{array}$ \\
\hline \multirow[t]{5}{*}{$\begin{array}{l}\text { Kim, Wells Jr., and Duffey } \\
\text { (2003), Vanhoucke (2012) }\end{array}$} & \multirow[t]{5}{*}{$\begin{array}{l}\text { Earned value } \\
\text { management }\end{array}$} & $\begin{array}{l}\text { Kerzner (2001), Andersen and Jessen (2003), } \\
\text { Cooke-Davies and Arzymanow (2003), Ahern, } \\
\text { Clouse, and Turner (2004) }\end{array}$ & $\begin{array}{l}\text { Maturity } \\
\text { assessment }\end{array}$ \\
\hline & & Calgar and Connolly (2007), Voss (2012) & $\begin{array}{l}\text { Interface } \\
\text { management }\end{array}$ \\
\hline & & $\begin{array}{l}\text { Kerzner (1987), Pinto and Slevin (1988), Miller } \\
\text { and Lessard (2000), Kappelman et al. (2007), } \\
\text { Klakegg et al. (2010) }\end{array}$ & $\begin{array}{l}\text { Extrapolation from } \\
\text { earlier projects }\end{array}$ \\
\hline & & $\begin{array}{l}\text { Nikander and Eloranata (2001), Klakegg et al. } \\
\text { (2010), Whitty (2010) }\end{array}$ & Gut feelings \\
\hline & & $\begin{array}{l}\text { Osborn (1953), Stroebe, Diehl, and } \\
\text { Abakoumkin (1992) }\end{array}$ & Brainstorming \\
\hline
\end{tabular}




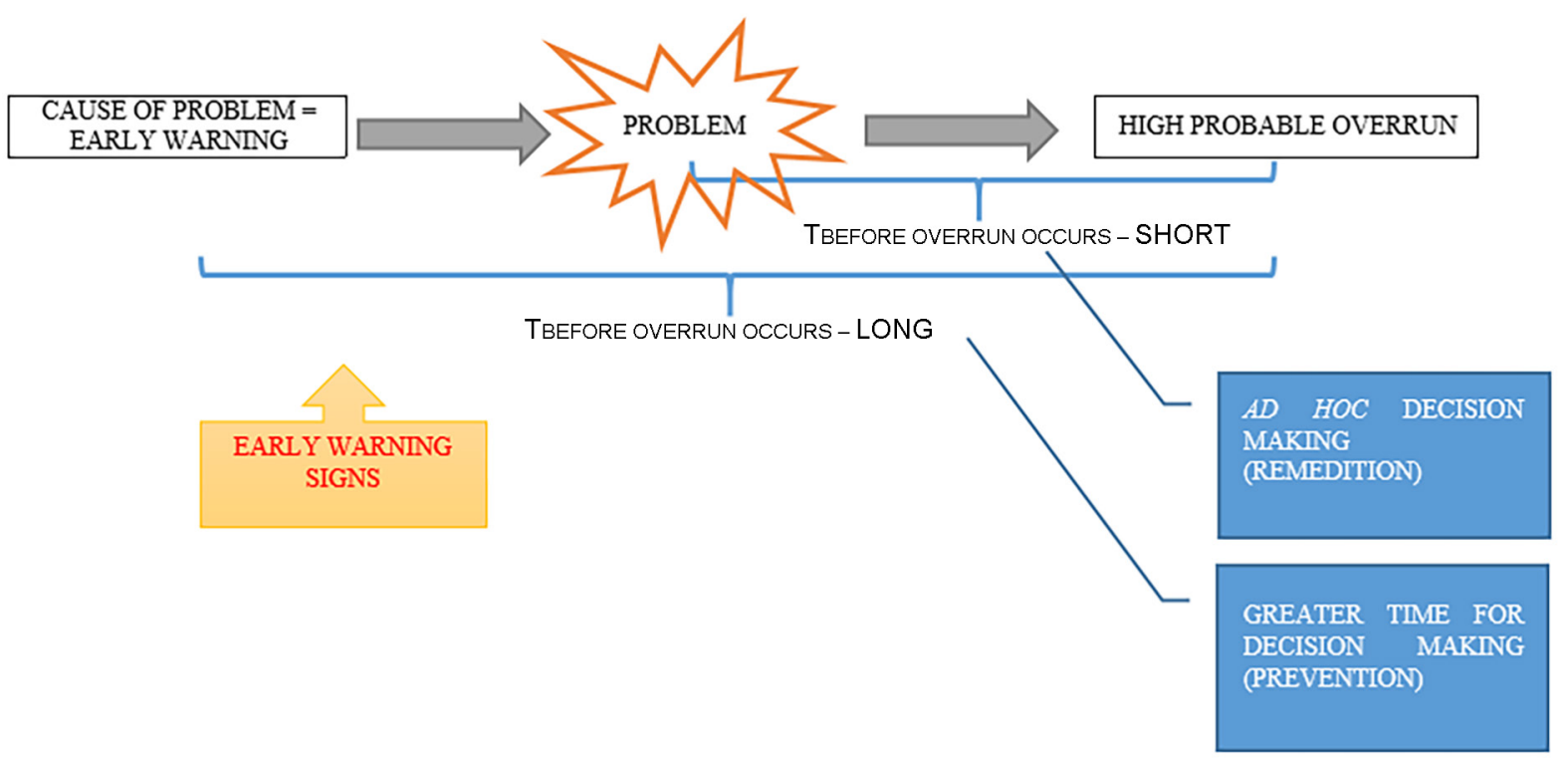

Figure 1. Ad hoc decision-making vs. decision-making based on prevention

the way up to complex multi-layered models that anticipate society, environmental, organizational, institutional and political needs.

Project success factors are elements that, if present, direct project towards success (Cooke-Davies, 2002). In other words, they represent project elements which can influence on the way to enhance possibility of success (Lim \& Mohamed, 1999; Muller \& Turner, 2007; Jari \& Bhangale, 2013). Since project success is consequence of project success criteria fulfilment, it can be stated that success factors enhance probability of fulfilment of success criteria, i.e. criteria are success measures and factors are success contributors (Jari \& Bhangale, 2013).

In context of direction of this research, project success factors were picked as a base for early warning detection and validation. Reasons for that decision are various and explained below. Nevertheless, project success criteria can also be integrated as a part of early warning systems on projects as given in Figure 2.

First of all, project success factors are success enablers, i.e. enablers of probability of reaching success criteria. It is not possible to influence on fulfilment of project success criteria on direct manner, or influence on project success evaluation directly. But, it is possible to influence on those elements that make that success more likely, that enhance chances that it will occur, and all of that by the means of project manager actions. Project success factors are always present on projects to some extent; they can be mostly easily detected at any time on project (unlike criteria, which fulfilment can be stated only at the end of the project). They are more dynamic than project success criteria, they tend to change, they can be influenced on, monitored and controlled, which makes them an ideal early warning indicator from research point of view.

If present on projects, they enhance project success. If absent on projects, or present insufficiently, they are a warning that successful project outcomes might not be reached. The strength of that warning is basically the significance of the missing success factor for an overall project success.

An algorithm of early warning system was developed as explained below. The development was inspired by cognitions on early warning system's constructive elements (modules), made by variety of other researchers (Ansoff, 1984; Austin, 2004; Nikander, 2002). Most of them stated that there are no clear guidelines in creation of early warning system, but, by studying relevant literature on early warning, it is possible to state certain activities which are attached to it:

- Early warning signs detection;

- Early warning signs interpretation and filtration;

- Selection of response to early warning signs.

Based on these activities, three different modules of early warning system were created:

- Module of early warning detection;

- Module of early warning validation;

- Module of early response.

Detection module relates to analysis and grades that project manager gives to the presence of critical success factors. This way of detection is even deepened with grading presence of project success factors that affect critical ones the most, all for the purpose of decreasing influence of possible inattentive grading.

Validation module depends on the strength of influence - i.e. significance, which low graded success factors have for overall project success.

Module of early response is accountable for giving clear guidelines for project managers on activities that they can take in order to act upon the warning and manage it effectively. The system gives recommendations for undertaking managerial activities through three different dimensions. 
FOCUS: PROJECT SUCCESS

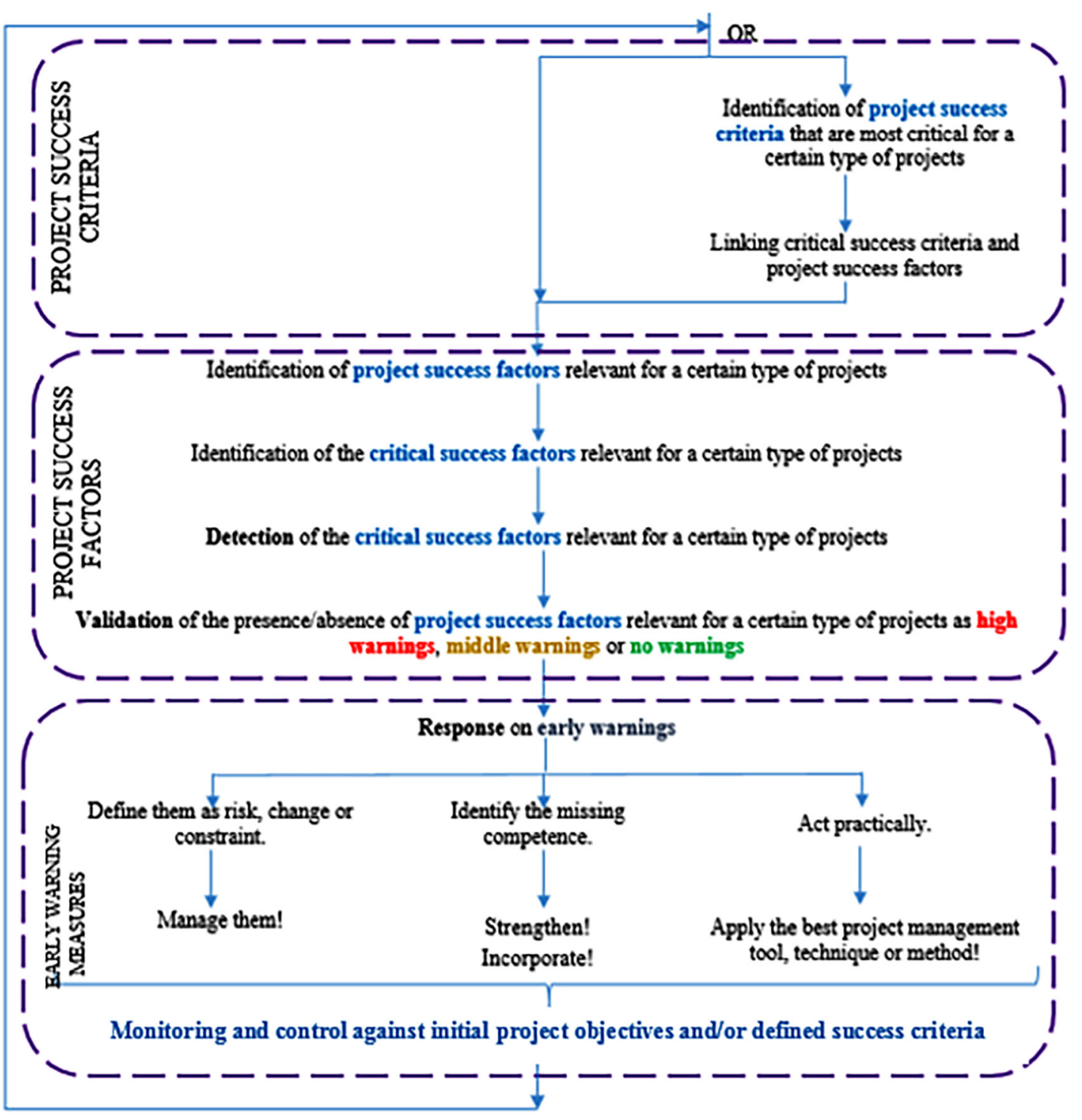

Figure 2. Early warning system's logic

The first dimension is attached to characterization of early warnings as risks, constraints or changes on a project. Namely, early warning signs are defined as any issue, information or sign, which can influence negatively on total success (Nikander, 2002; Ansoff, 1984; Kussi, 1999 according to Nikander, 2002; Austin, 2004; Kappelman et al., 2007). If we think about project success, authors came up with three possible elements which can threaten it - project risks, project constraints and changes on project. Project management is actually balancing between project goals on the one hand, and always present risks, changes and constraints on the other hand (Radujkovic, 2014). Therefore, applying well-known activities of risk, constraint or change management, depending on the characterization of early warning sign, may help in reducing negative influences on success. By doing so, it may be decided that risk will be avoided, transferred, mitigated or accepted.
Change may be avoided, reduced or accepted with stakeholders' approval. Constraints may be adjusted, or project bottlenecks expanded.

The second response dimension is related with competences of project management team that are not present, or are very weak, in a warning situation on a project. Competences are one of key pillar for directing towards success and may be developed by educational activities or external consultancy help.

Third dimension of response is linked with application of suitable project management tools, methods and techniques. They can be applied as the best practical solutions in managing, monitoring and controlling certain issues.

Reason why these three dimensions are selected as different sub sequences of early response module lies in various research results. Based on them, a positive relationship is shown between project success and risk management, 


\begin{tabular}{|c|}
\hline 1. STEP: Definition of success factors relevant for construction project group \\
\hline $\begin{array}{l}\text { Method: systematic literature review on project success factors, relative frequencies } \\
\text { calculation, Pareto principal application, focus group revision }\end{array}$ \\
\hline $\begin{array}{l}\text { 2. STEP: Measuring to which extent factors from previous step were present on } \\
\text { unsuccessful, mid-successful and successful projects in the sample }\end{array}$ \\
\hline Method: questionnare with Likert scale (1-5) \\
\hline 3. STEP: Definition of success factors that \\
\hline Method: linear regression analysis \\
\hline $\begin{array}{l}\text { 4. STEP: Definition of set of variables (suc } \\
\text { most important success factors } \mathrm{fr}\end{array}$ \\
\hline Method: linear regression analysis (stepwis \\
\hline 5. STEP: Creation of early warning detection module \\
\hline Methods: creative thinking \\
\hline 6. STEP: Creation of early warning validation module \\
\hline $\begin{array}{l}\text { Methods: creative thinking, usage of linear regression equations, B coefficients of } \\
\text { factors and project manager's grades from previous step }\end{array}$ \\
\hline 7. STEP: Creation of early warning response module \\
\hline $\begin{array}{l}\text { Methods: literature review, creative thinking in linking different dimensions of early } \\
\text { response, focus group, questionnare }\end{array}$ \\
\hline
\end{tabular}

Figure 3. Used methods in early warning system's creation

change management and constraint management (Dvir \& Lechler, 2004; Zavadskas, Turskis, \& Tamosaitiene, 2010; Burcar Dunovic, Radujkovic, \& Vukomanovic, 2016; Anees, Mohamed, \& Razek, 2013; Hwang, Zhao, \& Toh, 2014; Nahod, 2014; Chandra, 2015; Chen, Tsui, Dzeng, \& Wang, 2015; Radujkovic \& Sjekavica, 2017; Serpell, Ferrada, \& Rubio, 2017), project management competencies strengthening (Ika, 2009; Feger \& Thomas, 2012; Nahod, Vukomanovic, \& Radujkovic, 2013) and corresponding project management tools, methods and techniques application (Besner \& Hobbs, 2008; PricewaterhouseCoopers, 2012; Chou \& Ngo, 2014).

The methodology of making an early warning system and logic of acting upon it is shown on Figure 2 and Figure 3. Figure 3 also shows how this research idea can be implemented on other types of construction projects, by following steps in early warning system creation methodology. The logic stays the same, what may differ are success factors defined as critical ones on different types of construction projects.

The process of algorithm development, logic and its functional elements in details are given in Sjekavica (2017).

\section{Project success factors}

Project success factors are, as mentioned in Introduction, enhancers of success. They can be influenced on, they are always present on projects to some extent, and they are dynamic and might be identified, controlled and monitored. To define project success factors on which system will be based on, a systematic literature review was conducted. Using systematic literature review was of great help in decreasing chances of missing potentially important and valuable factors.

The first step was to identify main research question for the search: What are construction project success factors? Five search engines (EBSCO, Emerald Insight, Science Direct, Current Contents Connect - Web of Science, Hrcak) were searched by the key words: construction projects AND success factors. Search filters were set in terms of time span (published after January 2011), language (English), industry (Construction, Project Management) and reference type (Academic articles). Out of total number of 643 publications collected, double ones were put aside, which left authors with 621 publications. Then, a 
process of discarding publications began, based on criteria of answering research question. The decision of leaving publications for analysis was made in several phases - after reading publication's title (106 left), abstract (49 left), or the whole article (41 left). Then, several articles that addressed research question well were added from Google Scholar (19 publications). Also, publications that addressed research question from historically significant literature (21 of them) were added. This led to total number of 81 publications that were selected for analysis.

Analysis revealed 2418 project success factors mentioned in 81 publications, out of which 321 were mutually different ones. Because this number of project success factors was hard to manage in terms of examination of their presence on projects, a selection of factors to be included in the next step of research was made.

For 321 different project success factors, relative frequencies were calculated, based on Eqn (1):

$$
f_{F_{i}}=\frac{N_{A_{\left(F_{i}\right)}}}{N_{\text {total }}},
$$

where: $f_{F_{i}}$ - relative frequency of project success factor $F_{i}$ $(i=1,2, \ldots, 321) ; N_{A_{F_{i}}}$ - number of authors adverting project success factor ${ }^{{ }_{i}} F_{i}(i=1,2, \ldots, 321) ; N_{\text {total }}$ - total number of adverting of all project success factors.

Then, Pareto principal was applied (based on Rushton, Croucher, \& Baker, 2010), i.e. $20 \%$ of project success factors with greatest relative frequencies were used for further analyses (total number of 65 of them).

In order to ensure that all selected project success factors that were good targeted, a revision by focus group was made (based on Kitzinger, 2005).

Focus group consisted of seven project management experts, who had worked on infrastructure water projects. They were asked to revise selected project success factors, and define additional project success factors relevant for water projects besides them, if they found it necessary. Focus group added 18 additional factors, which led to a total number of 83 project success factors. Then, they fractured these factors into 108 variables - indicators which presence can be easily detected on a project level.

Also, they did an exercise which consisted of imagining that each one of 108 indicators were absent on project. They were asked to match the absence of each indicator with missing competence of project manager - technical, behavioural and contextual one. Competences were adopted from International Competence Baseline ${ }^{\circledR}$ (International Project Management Association, 2006). Also, they were asked to match the absence of each indicator with a project management tool, technique or method, which they considered to be the most helpful. The list of project management tools, techniques and methods was based on relevant literature review on the field (Fortune, White, Jugdev, \& Walker, 2011; Jugdev, Perkins, Fortune, White, \& Walker, 2013; Patanakul, Iewwongcharoen, \& Milosevic, 2010; Radujkovic et al., 2012; Drob \& Zichil, 2013; Ferreira, Tereso, Ribeiro, Fernandes, \& Loureiro, 2013).
By doing so, two out of the three dimensions of early response were set. What remained was to conduct a research on type of early waring (risk, change, constraint) and their connection to project success, which was done via survey.

\section{Survey, statistical analysis and results}

A survey was initially sent to ten project managers working in Croatian Governmental legal entity for water management (Croatian Waters) in charge for planning, undertaking, strategical governance and operative management of all kinds of water projects within Croatia. These project managers were selected as the most representative ones. Selection was based on the following criteria: a) civil engineering education (university degree - Master of Science or $\mathrm{PhD}$ in Engineering); b) certification in project management field (certified by PMI or IPMA); c) more than 12 years of experience; $d$ ) experience on managing complex water projects. The complexity of water projects was assumed via project value and duration, where project managers could be selected only if they managed projects with value higher than 50 million EUR and duration greater than 5 years.

Based on their professional expert judgment, they gave further recommendations which project managers should also be included in the sample, as they found them to be the most competent to answer the survey questions. These project managers came from various positions of contractors, utility companies, consultancy and project managers in Croatian Water's water-economy departments. Total 31 project managers got into the quantitative sample.

Most of the respondents were male $(65 \%)$, between 30 and 40 years old (45\%), with high qualification (84\%) and with educational background in construction (72\%). Respondents had an average of 12 years of work experience, out of which 10 in construction, and 8 in water projects. These are averaged values, so the respondent with the longest experience had 21 years of experience in managing projects. Average project that respondents had worked on lasted for three years and had financial value of 16.8 million EUR.

Project managers were given a list with 108 indicators, and they had to evaluate the presence of them on three of their projects (where one was perceived unsuccessful, one mid successful and one successful). The presence evaluation was made via Likert scale 1-5. Also, they had to identify the absence of each factor as risk, constraint or change for their project.

Since 31 project managers evaluated presence of 108 variables on 3 of their projects, a database of 93 projects was constructed. On the gathered data, a multiple linear regression analysis was used (by the means of a stepwise method), in statistical software IBM $₫$ SPSS ${ }$ Statistics (International Business Machines Corp., 2012). The results with corresponding statics in detailed are given in Sjekavica (2017). They showed that: 
Table 2. An example of matching characteristics of each factor used as early response

\begin{tabular}{|l|l|l|l|l|l|l|}
\hline \multirow{2}{*}{ Factor } & \multicolumn{2}{|c|}{$\begin{array}{c}\mathrm{RCC}^{1}-\text { based on } \\
\text { survey }\end{array}$} & $\begin{array}{l}\mathrm{RCC}^{1}- \\
\text { decision }\end{array}$ & \multicolumn{1}{|c|}{ Technical } & Behavioural & \multicolumn{2}{|c|}{$\begin{array}{c}\text { Project management tool, } \\
\text { Contextual } \\
\text { technique or method, that } \\
\text { contributes to minimization } \\
\text { of early warning }\end{array}$} \\
\hline $\begin{array}{l}\text { Political support } \\
\text { to the project } \\
\begin{array}{l}\text { does not exist } \\
\text { on a state level }\end{array}\end{array}$ & $\begin{array}{l}\mathrm{R}(\mathrm{f}=4 ; 12.9 \%) ; \\
\mathrm{Ch}(\mathrm{f}=5 ; 16.13 \%) ;\end{array}$ & Co $(\mathrm{f}=22 ; 70.97 \%)$ & $\begin{array}{l}\text { Interested } \\
\text { parties, } \\
\text { Communication }\end{array}$ & $\begin{array}{l}\text { Negotiation, } \\
\text { Consultation }\end{array}$ & $\begin{array}{l}\text { Permanent } \\
\text { organization, } \\
\text { Legal }\end{array}$ & $\begin{array}{l}\text { SWOT }^{2} \text { analysis, } \\
\text { PEST }^{3} \text { analysis... }\end{array}$ \\
\hline
\end{tabular}

Notes: ${ }^{1} \mathrm{R}$ - Risk; Ch - Change; Co - Constraint; f - frequency of response; ${ }^{2} \mathrm{SWOT}$ - Strengths, weaknesses, opportunities, threats; ${ }^{3} \mathrm{PEST}$ - political, economic, social, technological.

- All 108 variables explain 99\% of project success variability.

- Five critical factors that explain $53,8 \%$ of variability of project success are:

- Project manager coordinates the work of project participants successfully;

- Construction site management is of high quality;

- Political support to the project exists on a state level;

- Communication between project participants is of high quality;

- Relations between investor/client and other project participants are of high quality.

For each of these five factors, additional regression analysis was conducted, in order to get a set of factors that explain their variability. The results of additional analysis showed that two factors have to be evaluated directly, and 3 of them can be evaluated through another 25 factors. This led to total number of 30 factors.

Each of these 30 factors was defined as risk, constraint or change, based on the highest frequency of responses (see Table 2).

To each of 30 factors, the corresponding competences and tool, method or technique (based on the evaluation of focus group) was matched (see Table 2).

Results obtained via survey and statistical analyses where then used as input information in early warning algorithm. The algorithm logic is then transformed in Microsoft Excel $^{\circledR}$ (Microsoft Corporation, 2010), via which a user-friendly interface of a system was made (for more details see Sjekavica, 2017).

Basically, project manager has to evaluate the presence of 30 critical factors on a Likert scale (from 1 to 5) - two groups directly, and other three system calculates through formulae from linear regression analysis.
After that, system validates project manager's responses, by labeling factors with red (high early warning), yellow (middle warning) or green (no warning), by the logic given in Table 3 . In other words, if a factor is a significant factor or a suppressor variable, grades 1, 2 or 3 are validated as early warning, grade 4 as middle, and 5 as an absence of warning. For all other factors, grades 1 or 2 are validated as early warning, 3 as middle one, and 4 and 5 as absence of warning. Significance of a factor is defined by Beta coefficient from regression analysis.

For high, and then middle level of early warning, project manager is advised to react through three dimensions:

- See if an early warning sign is detected as risk, constraint or change. According to that, manage it through well-known practises of risk, constraint or change management (Table 4).

- Incorporate the missing competence shown by the system.

- Use the applicable tool, technique or method for managing projects. If there are limited financial, time or human resources in organization, use those with high $z$ values, because they are recognized as the one which can help minimize the greatest number of highly validated early warning signs at once.

An additional feature system has, is evaluation of project success on Likert scale (from 1 to 5), which is based on project managers assessment of success factors' presence and formula from linear regression analyses. This is valid for all projects with average value of grades of project success factors' presence between 2.56 and 4.78. These numbers present interval boundaries within which surveyed variables on projects from database can be found. In other words, early warning system is suitable for average projects, for extremely unsuccessful ones (general conditions

Table 3 . Visuals of early warning

\begin{tabular}{|l|c|c|c|}
\hline \multicolumn{1}{|c|}{ Category of variable } & Beta coefficient value & Variable presence grade & Colour that suggests type of warning \\
\hline \multirow{2}{*}{$\begin{array}{l}\text { Significant variables and suppressor } \\
\text { variables }\end{array}$} & $<0$ or $\geq 0.4$ & $1-3$ & High warning \\
\cline { 3 - 4 } & & 4 & Middle warning \\
\cline { 3 - 4 } & & 5 & No warning \\
\hline Less significant variables & $>0$ and $<0.4$ & $1-2$ & High warning \\
\cline { 3 - 4 } & & 3 & Middle warning \\
\cline { 3 - 4 } & & $4-5$ & No warning \\
\hline
\end{tabular}


Table 4. Activities of managing risks, changes and constraints

\begin{tabular}{|l|l|l|}
\hline \multicolumn{1}{|c|}{ Element } & \multicolumn{1}{|c|}{ Management activities } & \multicolumn{1}{|c|}{ Source } \\
\hline Risk & $\begin{array}{l}\text { 1. Plan risk management } \\
\text { 2. Identify risks } \\
\text { 3. Analyse risk qualitatively (risk assessment) } \\
\text { 4. Analyse risk quantitatively } \\
\text { 5. Plan risk response (Avoid, transfer, mitigate or accept) } \\
\text { 6. Respond to risk (Monitor and control risk) }\end{array}$ & $\begin{array}{l}\text { Project } \\
\text { Management } \\
\text { Institute } \\
(2013)\end{array}$ \\
\hline Change & $\begin{array}{l}\text { 1. Avoid change if possible (eliminate the need for change) } \\
\text { 2. Evaluate the influence of change on other project constraints } \\
\text { 3. Create possibility for change influence's reduction } \\
\text { 4. Get approval for change from the authority (project sponsor, project committee, client) } \\
\text { 5. Get approval for change from the user (if applicable) }\end{array}$ & $\begin{array}{l}\text { Project } \\
\text { Management } \\
\text { Institute } \\
\text { Constraint }\end{array}$ \\
$\begin{array}{l}\text { 1. Identify constraints on project } \\
\text { 2. Decide how to carry on with constraint } \\
\text { 3. Adjust unlimited project elements to decision how to carry on with constraint } \\
\text { 4. Broad narrow bottlenecks } \\
\text { 5. Get back on the first step to identify new constraints, revise defined constraints or less critical } \\
\text { constraints }\end{array}$ & $\begin{array}{l}\text { Goldratt } \\
(1997)\end{array}$ \\
\end{tabular}

\begin{tabular}{|c|c|c|c|c|c|c|c|c|}
\hline \multirow[b]{2}{*}{ ID } & \multicolumn{5}{|l|}{ EARLY WARNING SYSTEM } & \multicolumn{3}{|c|}{ MISSING PROJECT MANAGEMENT COMPETENCES } \\
\hline & PROJECT SUCCESS FACTORSIEARLY WARNNNG & G & Ponder & RChCo & Result & Technical & Behavioral & Contextual \\
\hline A1 & Project manager successfully coordinates work of project participants & 0.65 & 0.639 & c & 0.41 & Interested parties & Leadership & Project orientation \\
\hline 009 & Project goals are clearly and precisely defined. & 1 & 0.176 & Co & 0.18 & Project requirements \& objectives & Results orientation & Business \\
\hline 007 & Addressed scope of project manager's decision making is adequate to responsibility given to him/her on the project. & 3 & 0.158 & $\mathrm{R}$ & 0.47 & & & \\
\hline 008 & Supervising activities are being conducted effectively. & 4 & 0.182 & $\mathrm{R}$ & 0.73 & & & \\
\hline 001 & Imestorlclient makes compelent decisions. & 2 & 0.442 & $R$ & 0.88 & Interested parties & Consultation & Permanent organisation \\
\hline 005 & Organization of construction site is of high quality. & 5 & -0.291 & $\mathrm{R}$ & -1.46 & & & \\
\hline 010 & There is a clearly defined procedure of tisk management on the project: & 2 & -0.154 & Co & -0.31 & Risk \& opportunity & Creativity & Business \\
\hline 006 & There is elaborated system of monitoring and control of project costs. & 4 & -0.174 & Co & -0.70 & & & \\
\hline 002 & Project manager manitors and conirols project activites effectively. & 1 & 0.326 & $\mathrm{Ch}$ & 0.33 & Control \& reports & Leadership & Project orientation \\
\hline 003 & Project manager has working experience on similat projects. & 1 & 0.245 & co & 0.25 & Project management success & Engagement \& motivation & Personnel management \\
\hline 004 & Project manager adopis to changes quickly. & 1 & 0.275 & $\mathrm{R}$ & 0.28 & Changes & Efficiency & Project orientation \\
\hline
\end{tabular}

Figure 4. Part of initial early warning system user interference

rate $<2.56$ ) and for extremely successful ones (general conditions rate $>4.78$ ), system gives messages at the bottom of beginning interface:

- For projects with average conditions rate <2.56: "Your project is extremely problematic. Call a meeting of project management team and stakeholders and revise the concept of managing project".
- For projects with average conditions rate $>4.78$ : "Your project is doing well. Come back and check it later".

Figure 4 shows a part of possible interface of EWS. The process explained above could be automated or programmed on more extensive manner, which is outside the scope of this research, and could be one of the future directions in EWS development.

Table 5. Information of projects tested, and results of implementation attached to EWS

\begin{tabular}{|l|c|c|l|c|c|}
\hline Label & $\begin{array}{c}\text { Duration } \\
\text { category } \\
\text { (years) }\end{array}$ & $\begin{array}{c}\text { Total value } \\
\text { category } \\
\text { (mln. EUR) }\end{array}$ & Scope & $\begin{array}{c}\text { Perceived project } \\
\text { success from project } \\
\text { manager (1-5) }\end{array}$ & $\begin{array}{c}\text { Estimated } \\
\text { project success } \\
\text { based on EWS }\end{array}$ \\
\hline $\begin{array}{l}\text { Project } 1 \\
\text { (P1) }\end{array}$ & $<3$ & $13-26$ & $\begin{array}{l}\text { Construction and reconstruction of sewage and } \\
\text { water system, construction of waste water treatment } \\
\text { plant, supply of equipment, supervision }\end{array}$ & 3 & 2.79 \\
\hline $\begin{array}{l}\text { Project 2 } \\
\text { (P2) }\end{array}$ & $3-4$ & $<7$ & $\begin{array}{l}\text { Reconstruction of water system, construction and } \\
\text { reconstruction of sewage system, construction of } \\
\text { waste water treatment plant, supply of equipment, } \\
\text { supervision }\end{array}$ & 4 & 3.60 \\
\hline $\begin{array}{l}\text { Project 3 } \\
\text { (P3) }\end{array}$ & $>4$ & $7-13$ & $\begin{array}{l}\text { Construction of water and sewage system, } \\
\text { construction of waste water treatment plant, } \\
\text { supply of equipment, supervision, GIS (geographic } \\
\text { information system) implementation }\end{array}$ & 3 & 3.01 \\
\hline
\end{tabular}


Table 6. Results of early warning system implementation attached to data quality of recommendations in context of response to early warning

\begin{tabular}{|c|c|c|c|c|c|}
\hline Statement & $\mathrm{P} 1$ & $\mathrm{P} 2$ & P3 & M & $\mathrm{D}$ \\
\hline $\begin{array}{l}\text { Problems identified by the model correspond to the problems which are present on } \\
\text { projects in reality. }\end{array}$ & 7 & 7 & 6 & 6.7 & 7 \\
\hline $\begin{array}{l}\text { Suggested interventions in accordance to management activities attached to risks, } \\
\text { changes and constraints are useful for addressing identified problems. }\end{array}$ & 5 & 7 & 6 & 6.0 & - \\
\hline $\begin{array}{l}\text { Suggested interventions in accordance to competences are useful for addressing } \\
\text { identified problems. }\end{array}$ & 7 & 6 & 7 & 6.7 & 7 \\
\hline $\begin{array}{l}\text { Suggested interventions in accordance to project management tools, techniques and } \\
\text { methods are useful for addressing identified problems. }\end{array}$ & 6 & 6 & 5 & 5.7 & 6 \\
\hline $\begin{array}{l}\text { If EWS was implemented on the very beginning of the project, acting in accordance } \\
\text { to it would significantly contribute to project management. }\end{array}$ & 7 & 7 & 6 & 6.7 & 7 \\
\hline M (project's) & 6.4 & 6.6. & 6.0 & & \\
\hline $\mathrm{D}$ (project's) & 7 & 7 & 6 & & \\
\hline
\end{tabular}

Table 7. Results of early warning system implementation attached to usefulness of the system's help in project management knowledge areas based on Project Management Body of Knowledge Guide ${ }^{\circledR}$ (Project Management Institute, 2013)

\begin{tabular}{|c|c|c|c|c|c|}
\hline Project management knowledge area & $\mathrm{P} 1$ & $\mathrm{P} 2$ & P3 & M & $\mathrm{D}$ \\
\hline Project integration management & 7 & 7 & 7 & 7.0 & 7 \\
\hline Project scope management & 5 & 5 & 6 & 5.3 & 5 \\
\hline Project cost management & 7 & 7 & 6 & 6.7 & 7 \\
\hline Project time management & 7 & 7 & 6 & 6.7 & 7 \\
\hline Project quality management & 7 & 7 & 6 & 6.7 & 7 \\
\hline Project human resource management & 5 & 6 & 7 & 6.0 & - \\
\hline Project communications management & 6 & 6 & 7 & 6.3 & 6 \\
\hline Project risk management & 7 & 7 & 7 & 7.0 & 7 \\
\hline Project procurement management & 5 & 5 & 6 & 5.3 & 5 \\
\hline M (project's) & 6.22 & 6.33 & 6.44 & & \\
\hline $\mathrm{D}$ (project's) & 7 & 7 & 6 & & \\
\hline
\end{tabular}

Table 8. Results of early warning system implementation attached to project manager's perceptions on improvement of existing praxes in project management, increase of quality of monitoring and control, increase of probability for project success and project management success

\begin{tabular}{|c|c|c|c|c|c|}
\hline Questions & $\mathrm{P} 1$ & $\mathrm{P} 2$ & P3 & $\mathrm{M}$ & $\mathrm{D}$ \\
\hline $\begin{array}{l}\text { To which extent can early warning system's implementation improve future praxes in } \\
\text { project management? }\end{array}$ & 7 & 7 & 6 & 6.7 & 7 \\
\hline $\begin{array}{l}\text { To which extent can early warning system's implementation increase quality of project } \\
\text { monitoring and control? }\end{array}$ & 5 & 6 & 7 & 6.0 & - \\
\hline $\begin{array}{l}\text { To which extent can early warning system's implementation increase chances for } \\
\text { project success? }\end{array}$ & 5 & 6 & 6 & 5.7 & 6 \\
\hline $\begin{array}{l}\text { To which extent can early warning system's implementation increase chances for } \\
\text { project management success? }\end{array}$ & 6 & 6 & 7 & 6.3 & 6 \\
\hline $\mathrm{M}$ (project's) & 5.8 & 6.3 & 6.5 & & \\
\hline D (project's) & 5 & 6 & - & & \\
\hline
\end{tabular}




\section{Early warning system testing}

Early warning system was tested on three water projects, whose characteristics can be seen in Table 5. All of these projects had goals of improvement of collection and treatment of waste water according to European and national legislation, increase of level of connected people to public sewage and water system, improvement of water quality, protection of groundwater by sewage system remediation, protection of people, environment, ecosystem and natural resources, contribution to improvement of life and work conditions of people in project location.

Project managers were asked to test the system on their projects. After that, they were given the questionnaire, in which they were supposed to express their agreement with corresponding statements on the Likert scale (from 1 to 7 ). Their answers can be seen in Tables 6-8.

\section{Early warning system in regional context}

In order to inspect potential of wider regional usage of created early warning system, as well as to investigate relevance and possibilities of generalization of research findings, a further research step was made. A questionnaire has been set, consisting of two parts. In the first part, respondents had to give their opinion on the most significant fields on water projects, state of project management, as well as three dimensions of early response. In the second part, they had to evaluate on the Likert scale (1-5) and order within groups the most critical success factors that early warning system was based on, according to research made on Croatian water projects. Respondents were experts on the field of water projects management, and were randomly picked based on the following criteria: geographical affiliation to Central or South East Europe countries, working in construction industry, education background in construction, engineering, law or economy, at least university diploma or higher, certified project manager, experience in managerial functions, managed projects with budgets larger than 50 million EUR. Respondents work as team leaders/project managers, professors with project management experiences, CEOs or technical directors, main expert engineers or project management office specialists. Total number of 17 experts (4 from Czech Republic, 4 from North Macedonia, 4 from Serbia, 3 from Bosnia and Hercegovina and 2 from Slovenia) gave their expert opinions on several different parts of early warning system, results of which are elaborated below.

Respondents had to evaluate to which extent they consider critical variables belong to five groups that were detected as critical ones in Croatian research, as well to range them in accordance to their perceived significance (Table 9). What can be seen out of Table 9 is existence of general concurrence between critical success factor identified on national level and regional experts' opinion on their importance for project success. The average rate of belonging of a factor to specific category group is 4.4 , with minimum value of only 3.4 (given to active monitoring and management in accordance to political situation). This is also a factor with largest standard deviation in a group, which means that there is a division of opinions on significance of "political project management". This is quite understandable due to public perception of politics as something negative, not as a state's clear and objective strategy that determines overall funding and resource support to projects, especially in this regional context. Having in mind this explanation, it is seen that the rest four critical factors are graded 4.61 and higher, and are, along with "competent investor's decision-making" within top five best-fitted variables. This shows that it would be reasonable to expect that the critical areas on projects in national and regional contexts overlap.

The most important critical factor regarding recoded value of average rank $\left(\mathrm{M}_{\text {order }}\right)$ is successful coordination of project participants' work from project manager - what was in accordance with highest Betta coefficient from regression analysis. In subcategories division, authors found that averagely two of the highest rated factors due to linear regression are among top three ranked factors within groups. This again shows a reasonable overlap between critically Croatian and critically regional aspect of early warning system's factors selection.

In order to check these findings, it is also useful to consult qualitative part of this part of the research. Mapping between most significant parts of project management in regions and initial early warning system's is shown in Table 10. Only design documentation and elements of environment management are not covered within critical success factors of EWS. The reason behind this may lie in the fact that project manager in Croatia is appointed at the beginning of construction, not in defining phase, when design and feasibility aspects of sustainability are being made. Also, there have been often praxes in appointment of two managers - one dealing with project and design documentation, one with construction itself, depending on contract type.

In addition, an experts' opinion on three dimensions of early warning system is given in Table 11 . According to these data, it is seen that there is no systematic framework that combines any of three dimensions of early warning system (M range between 1.273 and 1.455). On the other hand, perceived usefulness in context of contribution to project success of such system ranges averagely from 3.773 to 4.000 ( 1 - would not contribute at all, 5 - would contribute very much), which is quite high.

The results of further research showed that it would be reasonable to expect success in EWS's implementation due to similarities of critical success factors on projects as well as project management problems in general, that countries in region share.

\section{Discussion}

Based on data given in Tables $5-8$, it is possible to conclude the following. 
Table 9. Results of testing of variables placement and order within critical factors' categories in EWS's

\begin{tabular}{|c|c|c|c|c|c|c|c|c|c|c|c|c|}
\hline ID & Project success factor & M & SD & $\mathrm{C}$ & $\mathrm{D}$ & S & Zs & $\mathrm{K}$ & $\mathrm{Zk}$ & Min & Max & $\mathrm{M}_{\text {order }}$ \\
\hline \multicolumn{13}{|c|}{ Top 5 critical success factors } \\
\hline $\mathrm{C} 1$ & $\begin{array}{l}\text { Project manager successfully } \\
\text { coordinates work of project } \\
\text { participants. }\end{array}$ & 4.89 & 0.471 & 5 & 5 & -4.243 & -7.911 & 18.000 & 17.344 & 3 & 5 & 3.71 \\
\hline $\mathrm{C} 2$ & $\begin{array}{l}\text { Communication between project } \\
\text { participants is of high quality. }\end{array}$ & 4.61 & 0.502 & 5 & 5 & -0.498 & -0.929 & -1.987 & -1.915 & 4 & 5 & 3.53 \\
\hline $\mathrm{C} 3$ & $\begin{array}{l}\text { Management of construction site is } \\
\text { of high-quality. }\end{array}$ & 4.83 & 0.383 & 5 & 5 & -1.956 & -3.647 & 2.040 & 1.966 & 4 & 5 & 3.00 \\
\hline $\mathrm{C} 4$ & $\begin{array}{l}\text { Interpersonal relations between } \\
\text { investor/client and other project } \\
\text { participants are of high quality. }\end{array}$ & 4.61 & 0.502 & 5 & 5 & -0.498 & -0.929 & -1.987 & -1.915 & 4 & 5 & 2.71 \\
\hline C5 & $\begin{array}{l}\text { There is political support to a project } \\
\text { on a state level. }\end{array}$ & 3.78 & 1.114 & 4 & 3 & -0.656 & -1.224 & 0.491 & 0.473 & 1 & 5 & 2.06 \\
\hline \multicolumn{13}{|c|}{ Project success factors within $\mathrm{C} 1$} \\
\hline $\mathrm{C} 1-1$ & $\begin{array}{l}\text { Project goals are clearly and precisely } \\
\text { defined. }\end{array}$ & 4.61 & 0.698 & 5 & 5 & -1.613 & -3.009 & 1.405 & 1.353 & 3 & 5 & 7.47 \\
\hline $\mathrm{C} 1-2$ & $\begin{array}{l}\text { Project manager monitors and } \\
\text { controls project activates effectively. }\end{array}$ & 4.56 & 0.705 & 5 & 5 & -1.354 & -2.524 & 0.654 & 0.630 & 3 & 5 & 6.80 \\
\hline $\mathrm{C} 1-3$ & $\begin{array}{l}\text { Supervising activities are being } \\
\text { conducted effectively. }\end{array}$ & 4.39 & 0.850 & 5 & 5 & -0.904 & -1.685 & -0.963 & -0.928 & 3 & 5 & 6.33 \\
\hline $\mathrm{C} 1-4$ & $\begin{array}{l}\text { Addressed scope of project manager's } \\
\text { decision making is adequate to } \\
\text { responsibility given to him/her on } \\
\text { the project. }\end{array}$ & 4.22 & 0.732 & 4 & 4 & -0.383 & -0.714 & -0.906 & -0.873 & 3 & 5 & 6.07 \\
\hline $\mathrm{C} 1-5$ & $\begin{array}{l}\text { There is a clearly defined procedure } \\
\text { of risk management on the project. }\end{array}$ & 4.39 & 0.778 & 5 & 5 & -0.852 & -1.588 & -0.706 & -0.681 & 3 & 5 & 5.40 \\
\hline C1-6 & $\begin{array}{l}\text { Investor/client makes competent } \\
\text { decisions. }\end{array}$ & 4.72 & 0.575 & 5 & 5 & -2.072 & -3.864 & 3.849 & 3.708 & 3 & 5 & 4.93 \\
\hline $\mathrm{C} 1-7$ & $\begin{array}{l}\text { Project manager adapts to changes } \\
\text { quickly. }\end{array}$ & 4.50 & 0.618 & 5 & 5 & -0.840 & -1.566 & -0.101 & -0.097 & 3 & 5 & 4.73 \\
\hline $\mathrm{C} 1-8$ & $\begin{array}{l}\text { There is elaborated system of } \\
\text { monitoring and control of project } \\
\text { costs. }\end{array}$ & 4.33 & 0.767 & 4.5 & 5 & -0.685 & -1.276 & -0.867 & -0.835 & 3 & 5 & 4.60 \\
\hline C1-9 & $\begin{array}{l}\text { Project manager has working } \\
\text { experience on similar projects. }\end{array}$ & 4.33 & 0.767 & 4.5 & 5 & -0.685 & -1.276 & -0.867 & -0.835 & 3 & 5 & 4.53 \\
\hline C1-10 & $\begin{array}{l}\text { Organization of construction site is } \\
\text { of high quality. }\end{array}$ & 4.61 & 0.608 & 5 & 5 & -1.362 & -2.539 & 1.126 & 1.085 & 3 & 5 & 4.13 \\
\hline \multicolumn{13}{|c|}{ Project success factors within C3 } \\
\hline C3-1 & $\begin{array}{l}\text { Organization of construction site is } \\
\text { of high quality. }\end{array}$ & 4.61 & 0.608 & 5 & 5 & -1.362 & -2.539 & 1.126 & 1.085 & 3 & 5 & 5.07 \\
\hline $\mathrm{C} 3-2$ & $\begin{array}{l}\text { Supervising activities are being } \\
\text { conducted effectively. }\end{array}$ & 4.39 & 0.850 & 5 & 5 & -0.904 & -1.685 & -0.963 & -0.928 & 3 & 5 & 5.07 \\
\hline C3-3 & $\begin{array}{l}\text { A timely/prompt start of project } \\
\text { execution has been provided. }\end{array}$ & 4.39 & 0.850 & 5 & 5 & -0.904 & -1.685 & -0.963 & -0.928 & 3 & 5 & 4.87 \\
\hline $\mathrm{C} 3-4$ & $\begin{array}{l}\text { Existing system of quality assurance } \\
\text { and control is effective. }\end{array}$ & 4.22 & 0.808 & 4 & 5 & -0.451 & -0.842 & -1.284 & -1.237 & 3 & 5 & 4.07 \\
\hline C3-5 & $\begin{array}{l}\text { Interpersonal relations between } \\
\text { contractor and other project } \\
\text { participants are of high quality. }\end{array}$ & 4.22 & 0.878 & 4 & 5 & -1.069 & -1.993 & 0.868 & 0.836 & 2 & 5 & 3.80 \\
\hline C3-6 & $\begin{array}{l}\text { Number of available machines and } \\
\text { equipment is sufficient. }\end{array}$ & 4.17 & 0.857 & 4 & 5 & -0.350 & -0.652 & -1.578 & -1.520 & 3 & 5 & 2.87 \\
\hline C3-7 & $\begin{array}{l}\text { Current relations between } \\
\text { construction and other industries are } \\
\text { supportive. }\end{array}$ & 4.06 & 0.725 & 4 & 4 & -0.086 & -0.160 & -0.904 & -0.871 & 3 & 5 & 2.27 \\
\hline
\end{tabular}


End of Table 9

\begin{tabular}{|c|l|c|c|c|c|c|c|c|c|c|c|c|c|}
\hline ID & \multicolumn{1}{|c|}{ Project success factor } & M & SD & C & D & S & Zs & K & Zk & Min & Max & $M_{\text {order }}$ \\
\hline Project success factors within C4 & 4.22 & 0.878 & 4 & 5 & -1.069 & -1.993 & 0.868 & 0.836 & 2 & 5 & 5.59 \\
\hline C4-1 & $\begin{array}{l}\text { Interpersonal relations between } \\
\text { contractor and other project } \\
\text { participants are of high quality. }\end{array}$ & 4.33 & 0.767 & 4.5 & 5 & -0.685 & -1.276 & -0.867 & -0.835 & 3 & 5 & 5.41 \\
\hline C4-2 & $\begin{array}{l}\text { Legal framework provides } \\
\text { unobstructed execution of project } \\
\text { activities. }\end{array}$ & 4.39 & 0.916 & 5 & 5 & -1.437 & -2.680 & 1.335 & 1.287 & 2 & 5 & 5.18 \\
\hline C4-3 & $\begin{array}{l}\text { Payments are being made on time. } \\
\text { C4-4 }\end{array}$ & $\begin{array}{l}\text { Top management of investor/client } \\
\text { actively supports project execution. }\end{array}$ & 4.44 & 0.705 & 5 & 5 & -0.915 & -1.706 & -0.252 & -0.242 & 3 & 5 & 4.88 \\
\hline C4-5 & $\begin{array}{l}\text { End users are consented with a } \\
\text { project. }\end{array}$ & 4.39 & 0.778 & 5 & 5 & -0.852 & -1.588 & -0.706 & -0.681 & 3 & 5 & 4.53 \\
\hline C4-6 & $\begin{array}{l}\text { Investor/client has been included } \\
\text { in planning and preparation of the } \\
\text { project and from the very beginning. }\end{array}$ & 4.33 & 0.840 & 4.5 & 5 & -1.413 & -2.636 & 2.219 & 2.139 & 2 & 5 & 3.88 \\
\hline C4-7 & $\begin{array}{l}\text { Investor's/client's change requests are } \\
\text { justified. }\end{array}$ & 4.28 & 0.752 & 4 & 5 & -0.529 & -0.986 & -0.933 & -0.899 & 3 & 5 & 3.47 \\
\hline C4-8 & $\begin{array}{l}\text { Project manager actively monitors } \\
\text { and manages project in accordance } \\
\text { to political situation. }\end{array}$ & 3.39 & 1.145 & 3 & 3 & -0.090 & -0.169 & -0.315 & -0.303 & 1 & 5 & 3.06 \\
\hline
\end{tabular}

Table 10. Results of qualitative analysis of project management success factors

\begin{tabular}{|l|c|c|}
\hline \multicolumn{1}{|c|}{ Named success factor } & $\mathrm{f}$ & Exists in national EWS \\
\hline Professional and competent project management & 13 & + \\
\hline Ensured project budget and timely payments & 10 & + \\
\hline Adequate legislative framework & 8 & \\
\hline Design documentation of high-quality & 7 & + \\
\hline Project manager's experience on similar projects & 7 & + \\
\hline Political support to a project & 8 & + \\
\hline Support and collaboration with institutional framework & 7 & + \\
\hline Relevant information from investor are accessible from the beginning & 5 & + \\
\hline Active support of end users & 5 & + \\
\hline Communication and coordination of all project participants & 4 & \\
\hline Environment management & 3 & \\
\hline Competent supervision & 3 & + \\
\hline Competent contractor and subcontractors & 3 & + \\
\hline Timely project start & 3 & + \\
\hline Project planning & 2 & + \\
\hline Quality assurance through sustainable project results & 2 & + \\
\hline No market distribution & 2 & + \\
\hline Understanding of project goals & 1 & + \\
\hline Qualified top management & 1 & + \\
\hline Good relationship with investor & & + \\
\hline
\end{tabular}


Table 11. Results on EWS dimensions' usefulness

\begin{tabular}{|c|c|c|c|c|c|c|}
\hline Question regarding EWS's dimension & M & $\mathrm{C}$ & $\mathrm{D}$ & SD & Min & $\operatorname{Max}$ \\
\hline $\begin{array}{l}\text { Is there any automatized system for monitoring and management of risks, } \\
\text { changes and constraints on project on your disposal? }\end{array}$ & 1.273 & 1 & 1 & 0.456 & 1 & 2 \\
\hline $\begin{array}{l}\text { Is there any automatized system for monitoring and management of } \\
\text { development of project manager's competences on your disposal? }\end{array}$ & 1.273 & 1 & 1 & 0.456 & 1 & 2 \\
\hline $\begin{array}{l}\text { Is there any automatized system for monitoring and management of } \\
\text { methods, tools and techniques for project management on your disposal? }\end{array}$ & 1.455 & 1 & 1 & 0.510 & 1 & 2 \\
\hline $\begin{array}{l}\text { How much would the introduction or development of automatized system } \\
\text { for monitoring and management of risks, changes and constraints on projects } \\
\text { contribute to success of water projects? ( } 1 \text { - would not contribute at all, } \\
5 \text { - would contribute very much) }\end{array}$ & 4.000 & 4 & 5 & 1.113 & 1 & 5 \\
\hline $\begin{array}{l}\text { How much would the introduction or development of automatized system } \\
\text { for monitoring and management of development of project manager's } \\
\text { competencies contribute to success of water projects? ( } 1 \text { - would not } \\
\text { contribute at all, } 5 \text { - would contribute very much) }\end{array}$ & 3.773 & 4 & 4 & 1.066 & 1 & 5 \\
\hline $\begin{array}{l}\text { How much would the introduction or development of automatized system } \\
\text { for monitoring and management of methods, tools and techniques for project } \\
\text { contribute to success of water projects? ( } 1 \text { - would not contribute at all, } \\
5 \text { - would contribute very much) }\end{array}$ & 3.864 & 4 & 5 & 1.125 & 1 & 5 \\
\hline
\end{tabular}

There is an extremely high congruence between perceived project success grade before the use of early warning system and estimated project success grade after its implementation on all three tested projects. This information suggests the value early warning system has in estimation of project outcome, which is one of its added values in detection, validation and answer to early warning.

Table 6 shows results of early warning system's implementation attached to data quality of recommendations in context of response to early warning. On all three projects, early warning system detected real present problems. In context of early response, project managers rated detection of missing competence as most useful one (with a total average grade of 6.7), then management activities attached to risks, changes and constraints (grade 6.0), and tolls, methods and technologies with the lowest grade (5.7). Project managers' opinions on contribution of implemented early warning system to project management is of extreme importance and is evaluated with a high average grade 6.7.

When it comes to project management areas on which early warning system's implementation influences the most, based on perception of project manager (Table 7), those are project integration management (average grade 7.0) and project risk management (7.0). They are followed by the iron triangle management - time, cost and quality (6.7 each), project communications management (6.3), human resources management (6.0) and finally, project scope and procurement management (5.3 each). These grades are basically reflection of areas covered with early warning system in the sense of those success factors that showed as critic ones, based on the study, and among which integration of project and its environment took the first place and procurement and scope the last one.
Table 8 shows results which are the most significant ones in validation of implementation of early warning system:

- Average rate of extent to which early warning system's implementation can improve future praxes in project management is 6.7 .

- Average rate of extent to which early warning system's implementation can increase quality of project monitoring and control is 6.0 .

- Average rate of extent to which early warning system's implementation can increase chances for project success is 5.7 .

- Average rate of extent to which early warning system's implementation can increase chances for project management success is 6.3 .

Based on presented data, high grade of perceived usefulness of all examined elements of early warning system's implementation can be seen on three different projects. This shows that it is possible to create and implement early warning system based on success factors as project success indicators in water sector, that can improve existing praxes in project management, increase quality of monitoring and control and increase chances for project success and project management success. By this, the main aim of this study is achieved, as well as the main research question answered.

In other words, we found it possible to create and implement early warning system on real projects, which was perceived useful in improvement of present praxes and making real change in becoming aware and solving project issues that really are the most significant ones for overall project success. Up to this point, this was seen only as a potential or partial indirect contribution through different 
present models and tools (Haji-Kazemi, 2013; Haji-Kazemi et al., 2015), and was not researched detailed enough on this innovative manner, even though early warning signs were proved to exist on projects (Nikander, 2002).

Moreover, we extended these findings on regional level in the selected countries in Central and South East Europe. We wanted to know if it would be reasonable to expect that early warning system created on the base of national water projects, may be found useful in other countries in regions as well, based on investigation of state of water projects' management in region. Regarding the data given in Tables 9-11, it is possible to conclude the following:

- Countries in regions share similar problems regarding water projects management.

- Qualitative analysis shows match to great extant with identified critical success factors that national early warning system was based on.

- In addition, quantitative analysis showed that identified factors according to linear regression on Croatian sample are quite well targeted in opinion of regional experts.

- There is no existence of anything similar to any of early warning system dimensions, but experts' opinion on usefulness of such dimensions in accordance to more successful project management is high.

It would be reasonable to expect that such an idea could be proven useful in regional context, with smaller adaptation of critical success factors ponders.

Findings that arise from this study are multifaceted. Besides the demonstrated usefulness of early warning system's implementation on projects, this study also has many other knowledge contributions. Five critical success factors of water projects are defined and based on them it is possible to explain $53.8 \%$ project success's variability. These five factors go far beyond traditional project management focus and indicate the need of public projects' managers to look upon their projects from different and broader perspectives (political, strategic) as well as to take care on soft management elements (communication, interpersonal relations). This finding is important in contributing to shift of general awareness of project success definition today. When speaking of managing projects in a world that is a global village, it becomes impossible to think about project success within the boundaries of iron triangle. And exactly this is shown through the most important success factors that were detected in this study - coordination, communication, relations, political support, management - those are things that make the difference between successful and unsuccessful projects. Of course, it is important to note that these factors may differ from one project type to another, but generally, the finding of broadening project success definition to multidimensional perspectives (political, community, stakeholders, environment, institutional, etc.) is consistent with other researchers (Khosravi \& Afshari, 2011; Howsawi, Eager, Bagia, \& Niebecker, 2014).

The idea of taking greater care of critical success factors on projects is not new, many other researchers identified different critical factors through their studies in different contexts (Enshassi, Mohamed, \& Abushaban, 2009; Gudiene et al., 2014; Liu, Skibniewski, \& Wang, 2016). What is new is the idea of linking those with the early warning knowledge. For the first time this kind of connection between project success factors as complete indicators of project success and project management success and knowledge of early warning is made - precisely, it is made by creation of early warning system in managing construction projects, which was then tested on example of water projects. As well, for the first time, the interpretation of early response through three dimensions of project management is made: management of risks, changes and constraints; competences for project management; and tools, techniques and methods for project management. By doing so, main theoretical contribution of this study is made. Also, by successful implementation of early warning system on concrete projects of water sector, the main practical contribution of this study is made, due to the fact that it is shown by the use of created early warning system that it is possible to create an useful tool for managing projects based on contribution in development of early warning system's creation, that offers new perspectives in managing decisions, project monitoring and control, and project management as general.

These findings mean that there is a huge potential in creating such systems in order to manage projects more successfully, dealing with the things that really are the most significant one on projects, by adopting possible solutions, which are easily understood, widely used, clear and simple.

Finally, based on this study, preconditions for new researches in creation and implementation of this and similar early warning systems in theory and practice are made.

Like any, this study also had its limitations. First, the first part of the research was conducted within Croatia, the country which does not have national methodology for evaluation of project success nor project management success. So, project managers were asked to evaluate existence of project success factors on three of their projects which they picked by themselves, based on their expert evaluation of success. Nevertheless, as project managers, they are the most responsible ones for project success, so they were the one who were the most competent to offer their grades from researchers' perspective. The project success may also be evaluated in accordance to critical success criteria that must be fulfilled in order to consider a project successful, if the model on those exists on specific level (state, project type, etc.).

To proceed, similar limitations existed in testing usefulness of created early warning system in implementation - again, this usefulness was the perceived one from the point of project managers. In trying to quantify the extant of increased project success, project management success and quality of project monitoring and control, it would be necessary to measure the parameters of these elements before and after early warning system's imple- 
mentation, with hypothesis of eliminating all of the other possible influences on them, what was simply not possible, due to the dynamic nature of projects' environments. Alternative, it would be needed to monitor defined parameters on two similar projects, while the one would have implemented early warning system, and the other would not. However, from the definition of the project as unique human endeavor (Project Management Institute, 2013), it is possible to see that there is no such thing as two $100 \%$ same projects. Even if there were, there is no such thing as defined parameters of project success because the consensus definition of project success is still missing, as stated in Introduction (Pinto \& Slevin, 1988; Baccarini, 1999; Ika, 2009; McLeod et al., 2012).

One of the study's limitations relates to initial database created in Croatian, i.e. national context. But this country may serve as an example of similar countries from South East and Central Europe. It would be reasonable to expect that the results of this study can be generalized on other European countries as shown in the fifth part of the study. This generalization may be made based on similarities of economy and construction sectors with other countries from this regional group (Eurostat, 2018). For other countries, this model can be helpful in trying to develop their industries and increase chances for greater construction success.

\section{Conclusions}

Projects are integral part of the present, and their success is the core aspiration of any project management activity, taken under the requirements of dynamic and multiple complex project environment, which may often be a framework for many project management challenges. In order to contribute to possible solutions of these, a research was undertaken. The results showed that it is possible to increase chances for successful project management by creating and implementing EWS. The main theoretical contribution lies in materialization of the idea of linking project success and early warning concepts through project success factors, as well as building early response through three project management dimensions. Based on these findings, it is possible to build up a useful tool that can help project managers manage their projects on more successful manner, which is a basic practical contribution of the study. Despite on focusing on specific types of projects, research confirmed that it is possible to develop a model which is regionally applicable with minor adjustment, and where analogous approach may be used for EWS development on different project types.

Possible future research directions may integrate relations between project success factors and project success criteria in early warning systems, develop early warning systems applicable to different project types or investigate phenomena of early warning system's alerts filtration and interpretation in praxes.

\section{Acknowledgements}

The Authors would like to thank to the Croatian Water, national agency for water of Croatia, for the support in providing relevant data for the research and its staff for participation in the survey needed for the research. The Authors also acknowledge to the University of Zagreb, Faculty of Civil Engineering, Zagreb, Croatia for the institutional support for the research and especially to the academic staff of Construction Management and Economics Department for providing valuable feedbacks during the research. In addition, authors would like to thank to the Central and South East Europe project management experts for providing valuable data on checking research proposed approach.

\section{Disclosure statement}

The Authors declare no conflict of interest from other parties.

\section{References}

Abdul-Rahman, H., Wang, C. \& Muhammad, N. B. (2011). Project performance monitoring methods used in Malaysia and perspectives of introducing EVA as a standard approach. Journal of Civil Engineering and Management, 17(3), 445-455. https://doi.org/10.3846/13923730.2011.598331

Ahern, D., Clouse, A., \& Turner, R. (2004). A practical introduction to integrated process improvement ( $2^{\text {nd }} \mathrm{ed}$.). Boston: Addison-Wesley.

Andersen, E. S., \& Jessen, S. A. (2003). Project maturity in organizations. International Journal of Project Management, 21(6), 457-461. https://doi.org/10.1016/S0263-7863(02)00088-1

Anees, M. M., Mohamed, H. E., \& Razek, M. E. A. (2013). Evaluation of change management efficiency of construction contractors. HBRC Journal, 9(1), 77-85.

https://doi.org/10.1016/j.hbrcj.2013.02.005

Ansoff, H. I. (1975). Managing strategic surprise by response to weak signals. California Management Review, 18(2), 21-33. https://doi.org/10.2307/41164635

Ansoff, H. I. (1984). Implanting strategic management. New Jersey: Pretince/Hall International Inc.

Austin, A. (2004). Early warning and the field: a cargo cult science? Transforming ethnopolitical conflict. In B. Austin, V. Dudouet, \& H. J. Giessmann (Eds.). Berghof handbook for conflict transformation (pp. 129-150). Wiesbaden: VS Verlag für Sozialwissenschaften. https://doi.org/10.1007/978-3-663-05642-3_7

Azeem, S. A., Hosny, H. E., \& Ibrahim, A. H. (2014). Forecasting project schedule performance using probabilistic and deterministic models. HBRC Journal, 10(1), 35-42. https://doi.org/10.1016/j.hbrcj.2013.09.002

Baccarini, D. (1999). The logical framework method for defining project success. Project Management Journal, 30(4), 25-32. https://doi.org/10.1177/875697289903000405

Bannerman, P. L. (2008). Defining project success: A multilevel framework. In Proceedings of the Project Management Institute Research Conference (pp. 1-14). Warsaw, Poland.

Besner, C., \& Hobbs, B. (2008). Project management practice, generic or contextual: A reality check. Project Management Journal, 39(1), 16-33. https://doi.org/10.1002/pmj.20033 
Burcar Dunovic, I., Radujkovic, M., \& Vukomanovic, M. (2016). Internal and external risk based assessment and evaluation for the large infrastructure projects. Journal of Civil Engineering and Management, 22(5), 673-682.

https://doi.org/10.3846/13923730.2015.1128479

Calgar, J., \& Connolly, M. (2007). Interface management: effective information exchange through improved communication. Texas: ABB Value Paper SeriesABB.

Chandra, H. P. (2015). Structural equation model for investigating risk factors affecting project success in Surabaya. Procedia Engineering, 125, 53-59. https://doi.org/10.1016/j.proeng.2015.11.009

Chen, C. S., Tsui, Y. K., Dzeng, R. J., \& Wang, W. C. (2015). Application of project-based change management in construction: a case study. Journal of Civil Engineering and Management, 21(1), 107-118.

https://doi.org/10.3846/13923730.2013.802712

Chou, J. S., \& Ngo, N. T. (2014). Identifying critical project management techniques and skills for construction professionals to achieving project success. In Proceedings of 2014 International Conference on Industrial Engineering and Engineering Management (pp. 1204-1208). Malaysia. https://doi.org/10.1109/IEEM.2014.7058829

Cleland, D. I. (1986). Measuring success: the owner's viewpoint. In Proceedings of the $18^{\text {th }}$ Annual Seminar/Symposium (pp. 6-12). Montreal, Canada.

Cooke-Davies, T. (2002). The "real" success factors on projects. International Journal of Project Management, 20(3), 185-190. https://doi.org/10.1016/S0263-7863(01)00067-9

Cooke-Davies, T. J., \& Arzymanow, A. (2003). The maturity of project management in different industries: an investigation into variations between project management models. International Journal of Project Management, 21(6), 471-478. https://doi.org/10.1016/S0263-7863(02)00084-4

Cooper, R. G. (2005). Product leadership: Pathways to profitable innovation ( $2^{\text {nd }}$ ed.). New York: Basic Books.

Cooper, R. G., Edgett, S. J., \& Kleinschmidt, E. J. (1997). Portfolio management in new product developments: lessons from the leaders. Research-Technology Management, 40(5), 16-28. https://doi.org/10.1080/08956308.1997.11671152

Drob, C., \& Zichil, V. (2013). Overview regarding the main guidelines, standards and methodologies used in project management. Journal of Engineering Studies and Research, 19(3), 26-31. https://doi.org/10.29081/jesr.v19i3.113

Dvir, D., \& Lechler, T. (2004). Plans are nothing, changing plans is everything: the impact of changes on project success. Research Policy, 33(1), 1-15. https://doi.org/10.1016/j.respol.2003.04.001

Enshassi, A., Mohamed, S., \& Abushaban, S. (2009). Factors affecting the performance of construction projects in the Gaza strip. Journal of Civil Engineering and Management, 15(3), 269-280. https://doi.org/10.3846/1392-3730.2009.15.269-280

Eurostat. (2018). Construction production (volume) index overview. Retrieved from http://ec.europa.eu/eurostat/statisticsexplained/index.php/Construction_production_(volume)_ index_overview

Feger, A. L. R., \& Thomas, G. A. (2012). A framework for exploring the relationship between project manager leadership style and project success. The International Journal of Management, 1(1), 1-19. https://doi.org/10.22367/jem.2017.30.01

Ferreira, M., Tereso, A., Ribeiro, P., Fernandes, G., \& Loureiro, I. (2013). Project management practices in private Portuguese organizations. Procedia Technology, 9, 608-617. https://doi.org/10.1016/j.protcy.2013.12.067
Fleming, Q. W., \& Koppelman, J. M. (1998, July). Earned value project management: A powerful tool for software project. Crosstalk: The Journal of Defense Software Engineering, 19-23.

Fortune, J., White, D., Jugdev, K., \& Walker, D. (2011). Looking again at current practice in project management. International Journal of Managing Projects in Business, 4(4), 553-572. https://doi.org/10.1108/17538371111164010

Goldratt, E. M. (1997). Critical chain. Great Barrington: The North River Press.

Gudiene, N., Banaitis, A., Podvezko, V., \& Banaitiene, N. (2014). Identification and evaluation of the critical success factors for construction projects in Lithuania: AHP approach. Journal of Civil Engineering and Management, 20(3), 350-359. https://doi.org/10.3846/13923730.2014.914082

Gunathilaka, S., Tuuli, M. M., \& Dainty, A. R. (2013). Critical analysis of research on project success in construction management journals. In Proceedings of $29^{\text {th }}$ Annual ARCOM Conference, 2-4 September 2013, Reading, United Kingdom (pp. 979-988).

Haji-Kazemi, S., Andersen, B., \& Klakegg, O. J. (2015). Barriers against effective responses to early warning signs in projects. International Journal of Project Management, 33(5), 10681083. https://doi.org/10.1016/j.ijproman.2015.01.002

Haji-Kazemi, S., Andersen, B., \& Krane, H. P. (2013). A review on possible approaches for detecting early warning signs in projects. Project Management Journal, 44(5), 55-69. https://doi.org/10.1002/pmj.21360

Havelka, D. \& Rajkumar, T. (2006). Using the troubled project recovery framework: problem recognition and decision to recover. E-Service Journal, 5(1), 43-73. https://doi.org/10.2979/esj.2006.5.1.43

Howsawi, E., Eager, D., Bagia, R., \& Niebecker, K. (2014). The four-level project success framework: application and assessment. Organisational Project Management, 1(1), 1-15. https://doi.org/10.5130/opm.v1i1.3865

Hwang, B. G., Zhao, X., \& Toh, L. P. (2014). Risk management in small construction projects in Singapore: status, barriers and impact. International Journal of Project Management, 32(1), 116-124. https://doi.org/10.1016/j.ijproman.2013.01.007

Ika, L. A. (2009). Project success as a topic in project management journals. Project Management Journal, 40(4), 6-19. https://doi.org/10.1002/pmj.20137

International Business Machines Corp. (2012). IBM ${ }^{\triangleright} S P S S^{\oplus}$ Statistics version 21 . Software.

International Project Management Association. (2006). ICB: International Competence Baseline ${ }^{\circledast}$ version 3.0.

Jaafari, A. (2007). Project and program diagnostics: a systemic approach. International Journal of Project Management, 25(8), 781-790. https://doi.org/10.1016/j.ijproman.2007.05.008

Jari, A. J., \& Bhangale, P. P. (2013). To study critical factors necessary for a successful construction project. International Journal of Innovative Technology and Exploring Engineering, 2(5), 331-335.

Jugdev, K., Perkins, D., Fortune, J., White, D., \& Walker, D. (2013). An exploratory study of project success with tools, software and methods. International Journal of Managing Projects in Business, 6(3), 534-551. https://doi.org/10.1108/IJMPB-08-2012-0051

Kapliński, O. (2008). Usefulness and credibility of scoring methods in construction industry. Journal of Civil Engineering and Management, 14(1), 21-28. https://doi.org/10.3846/1392-3730.2008.14.21-28

Kappelman, L. A., McKeeman, R., \& Zhang, L. (2007). Early warning signs of IT project failure: The dominant dozen. 
EDPACS: The EDP Audit, Control, and Security Newsletter, 35(1), 1-10. https://doi.org/10.1201/1078.10580530/46352.23 $.4 .20060901 / 95110.4$

Kerzner, H. (1987). In search of excellence in project management. Journal of Systems Management, 38(2), 30-39.

Kerzner, H. (2001). Strategic planning for project management using a maturity model. New York: John Wiley \& Sons.

Khosravi, S., \& Afshari, H. (2011). A success measurement model for construction projects. In Proceedings of International Conference on Financial Management and Economics (IPEDR) (pp. 186-190). Singapore.

Kim, B. C. (2007). Forecasting project progress and early warning of project overruns with probabilistic methods (Doctoral dissertation). Texas A\&M University, United States of America.

Kim, E. H., Wells Jr., W. G., \& Duffey, M. R. (2003). A model for effective implementation of earned value management methodology. International Journal of Project Management, 21(5), 375-382. https://doi.org/10.1016/S0263-7863(02)00049-2

Kitzinger, J. (2005). Focus group research: using group dynamics to explore perceptions, experiences and understandings. In I. Holloway (Ed.), Qualitative research in health care (pp. 5670). Maidenhead: Open University Press.

Klakegg, O. J., Andersen, B., Williams, T., Walker, D., \& Magnussen, O. M. (2010). Early warning signs in complex projects. Newton Square: Project Management Institute.

Kuusi, O. (1999). Teknologisen kehityksen heikot signaalit. Futura, 18(2).

Leavy, P. (2014). The Oxford handbook of qualitative research. New York: Oxford University Press. https://doi.org/10.1093/oxfordhb/9780199811755.001.0001

Lee, H. S., Lee, K. P., Park, M., Baek, Y., \& Lee, S. (2011). RFIDbased real-time locating system for construction safety management. Journal of Computing in Civil Engineering, 26(3), 366-377. https://doi.org/10.1061/(ASCE)CP.19435487.0000144

Leszak, M., Perry, D. E., \& Stoll, D. (2000). A case study in root cause defect analysis. In Proceedings of $22^{\text {nd }}$ International Conference on Software Engineering (pp. 428-437). Limerick, Ireland. https://doi.org/10.1145/337180.337232

Lim, C. S., \& Mohamed, M. Z. (1999). Criteria of project success: an exploratory re-examination. International Journal of Project Management, 17(4), 243-248.

https://doi.org/10.1016/S0263-7863(98)00040-4

Liu, H., Skibniewski, M. J., \& Wang, M. (2016). Identification and hierarchical structure of critical success factors for innovation in construction projects: Chinese perspective. Journal of Civil Engineering and Management, 22(3), 401-416. https://doi.hr/10.3846/13923730.2014.975739

Lowe, D. (2016). Use early warning indicators as a management tool. Retrieved from http://www.dolowe.org

Mavrotas, G., Caloghirou, Y., \& Koune, J. (2005). A model on cash flow forecasting and early warning for multi-project programmes: application to the Operational Programme for the Information Society in Greece. International Journal of Project Management, 23(2), 121-133. https://doi.org/10.1016/j.ijproman.2004.07.009

McLeod, L., Doolin, B., \& MacDonell, S. G. (2012). A perspective-based understanding of project success. Project Management Journal, 43(5), 68-86. https://doi.org/10.1002/pmj.21290

Microsoft Corporation. (2010). Microsoft Excel ${ }^{\circ}$. Software.

Miller, R., \& Lessard, D. R. (2000). The strategic management of large engineering projects: Shaping institutions, risks, and governance. Cambridge: MIT Press. https://doi.org/10.7551/mitpress/6478.001.0001
Mir, F. A., \& Pinnington, A. H. (2014). Exploring the value of project management: Linking project management performance and project success. International Journal of Project Management, 32(2), 202-217.

https://doi.org/10.1016/j.ijproman.2013.05.012

Molenaar, K. R., Javernick-Will, A., Bastias, A. G., Wardwell, M. A., \& Saller, K. (2013). Construction project peer reviews as an early indicator of project success. Journal of Management in Engineering, 29(4), 327-333.

https://doi.org/10.1061/(ASCE)ME.1943-5479.0000149

Montgomery, D. C., \& Runger, G. C. (2014). Applied statistics and probability for engineers. New Jersey: Wiley.

Muller, R., \& Turner, R. (2007). The influence of project managers on project success criteria and project success by type of project. European Management Journal, 25(4), 298-309. https://doi.org/10.1016/j.emj.2007.06.003

Nahod, M. M. (2014). Impact of competent managing the changes on project success (Doctoral dissertation). Faculty of Civil Engineering, University of Zagreb, Croatia.

Nahod, M. M., Vukomanovic, M., \& Radujkovic, M. (2013). The impact of ICB 3.0 competences on project management success. Procedia - Social and Behavioral Sciences, 74, 244-254. https://doi.org/10.1016/j.sbspro.2013.03.014

Navon, R., \& Kolton, O. (2006). Model for automated monitoring of fall hazards in building construction. Journal of Construction Engineering and Management, 132(7), 733-740. https://doi.org/10.1061/(ASCE)0733-9364(2006)132:7(733)

Nikander, I., \& Eloranta, E. (2001). Project management by early warnings. International Journal of Project Management, 19(7), 385-399. https://doi.org/10.1016/S0263-7863(00)00021-1

Nikander, I. O. (2002). Early warnings: A phenomenon in project management (Doctoral dissertation). Helsinki University of Technology, Finland.

Niwa, K. (1989). Knowledge-based risk management in engineering. New York: Wiley.

Ohatka, F., \& Fukazawa, Y. (2009). Managing risk symptom: a method to identify major risks of serious problem projects in SI environment using cyclic causal model. Project Management Journal, 41(1), 51-60. https://doi.org/10.1002/pmj.20144

Osborn, A. F. (1953). Applied imagination: Principles and procedures of creative problem solving ( $3^{\text {rd }} \mathrm{ed}$.). New York: Charles Scribner's Sons.

Parker, S. K., \& Skitmore, M. (2005). Project management turnover: causes and effects on project performance. International Journal of Project Management, 23(3), 205-214. https://doi.org/10.1016/j.ijproman.2004.10.004

Patanakul, P., Iewwongcharoen, B., \& Milosevic, D. (2010). An empirical study on the use of project management tools and techniques across project life-cycle and their impact on project success. Journal of General Management, 35(3), 41-65. https://doi.org/10.1177/030630701003500304

Philip, T., Schwabe, G., \& Wende, E. (2010). Identifying early warning signs of failures in offshore software development projects - A Delphi survey. In Proceedings of the $16^{\text {th }}$ Americas Conference on Information Systems (pp. 462-470). Lima, Peru.

Pinto, J. K., \& Slevin, D. P. (1988). Critical success factors across the project life cycle. Project Management Journal, 19(3), 6775.

Pinto, J. K., \& Slevin, D. P. (1992). Project implementation profile. SAD: XICOM Inc.

PricewaterhouseCoopers. (2012). PWC insights and trends: Current portfolio, programme and project management practices $3^{\text {rd }}$ Global survey on the current state of project management. 
PricewaterhouseCoopers International Limited. Retrieved from https://www.pwc.com.tr/en/publications/arastirmalar/ pages/pwc-global-project-management-report-small.pdf

PricewaterhouseCoopers. (2014). Capital project and infrastructure spending: Outlook to 2025. PricewaterhouseCoopers International Limited. Retrieved from https://www.pwc. com/gx/en/capital-projects-infrastructure/publications/cpioutlook/assets/cpi-outlook-to-2025.pdf

Project Management Institute. (2013). Project management body of knowledge guide (5 $5^{\text {th }}$ ed.).

Project Management Institute. (2016). The high cost of low performance: How will you improve business results? Retrieved from http://www.pmi.org/-/media/pmi/documents/public/pdf/ learning/thought-leadership/pulse/pulse-of-the-profession-2016.pdf

Radujkovic, M. (2014). Project management and its impact on society in $21^{\text {st }}$ century. Keynote lecture. In Seminario Internacional Direccion de Proyectos Desafious Actuales y futures. Santiago de Chile, Pontifica Universidad Catolica de Chile, Centro de Extension UC Alameda.

Radujkovic, M., \& Sjekavica, M. (2017). Project management success factors. Procedia Engineering, 196, 607-615. https://doi.org/10.1016/j.proeng.2017.08.048

Radujkovic, M., Car Pusic, D., Ostojic Skomrlj, N., Vukomanovic, M., Burcar Dunovic, I., Delic, D., \& Mestrovic, H. (2012). Planiranje $i$ kontrola projekata. Zagreb: University of Zagreb, Faculty of Civil Engineering.

Rushton, A., Croucher, P., \& Baker, P. (2010). The handbook of logistics and distribution management ( $4^{\text {th }}$ ed.). London: Kogan Page.

Sambasivan, M., \& Soon, W. Y., (2007). Causes and effects of delays in Malaysian construction industry. International Journal of Project Management, 25(5), 517-526.

https://doi.org/10.1016/j.ijproman.2006.11.007

Savage, G. T., Nix, T. W., Whitehead, C. J., \& Blair, J. D. (1991). Strategies for assessing and managing organizational stakeholders. Academy of Management Perspectives, 5(2), 6-75. https://doi.org/10.5465/ame.1991.4274682

Schoper, Y.-G., Wald, A., Thor Ingason, H., \& Vikingur Fridgeirsson, T. (2018). Projectification in Western economies: A comparative study of Germany, Norway and Iceland. International Journal of Project Management, 6(1), 71-82. https://doi.org/10.1016/j.ijproman.2017.07.008

Serpell, A., Ferrada, X., \& Rubio, N. L. (2017). Fostering the effective usage of risk management in construction. Journal of Civil Engineering and Management, 23(7), 858-867. https://doi.org/10.3846/13923730.2017.1321578

Shenhar, A. J. (2001). One size does not fit all projects: Exploring classical contingency domains. Management Science, 47(3), 394-414. https://doi.org/10.1287/mnsc.47.3.394.9772
Sjekavica, M. (2017). Early warning system in managing construction projects (Doctoral dissertation). Zagreb: University of Zagreb, Faculty of Civil Engineering.

Skibniewski, M. J. (2014). Information technology applications in construction safety assurance. Journal of Civil Engineering and Management, 20(6), 778-794. https://doi.org/10.3846/13923730.2014.987693

Spjelkavik, I., Andersen, B., Onsoyen, L. E., Fagerhaug, T., \& Marheim, H. (2008). Project performance management system: a conceptual framework for early warnings in projects. In Proceedings of the 22 $2^{\text {nd }}$ IPMA World Congress (pp. 89-93). Rome, Italy.

Standish Group. (2013). Chaos manifesto 2013 - Think big, act small. Retrieved from https://www.immagic.com/eLibrary/ ARCHIVES/.../S130301C.pdf

Stroebe, W., Diehl, M., \& Abakoumkin, G. (1992). The illusion of group effectivity. Personality and Social Psychology Bulletin, 18(5), 643-650. https://doi.org/10.1177/0146167292185015

Vanhoucke, M. (2012). Measuring the efficiency of project control using fictitious and empirical project data. International Journal of Project Management, 30(2), 252-263. https://doi.org/10.1016/j.ijproman.2011.05.006

Vondruska, M. (2014). Early warning system for detection of the crisis in construction projects. In Proceedings of Creative Construction Conference 2014 (pp. 383-388). Prague, Czech Republic.

Voss, M. (2012). Impact of customer integration on project portfolio management and its success: developing a conceptual framework. International Journal of Project Management, 30(5), 567-581.

https://doi.org/10.1016/j.ijproman.2012.01.017

Wang, K., Zhang, X., Wang, X., \& Yu, J. (2009). Establishment of construction safety early-warning system for mountainous freeways. In Proceedings of the $9^{\text {th }}$ International Conference of Chinese Transportation Professionals (ICCTP). Harbin, China. https://doi.org/10.1061/9780784410646

Wateridge, J. (2002). (Post) project evaluation review. In Project Management Pathways (pp. 65-1-65-12). High Wycombe: Association for Project Management.

Whitty, S. J. (2010). Project management artifacts and the emotions they evoke. International Journal of Managing Projects in Business, 3(1), 22-45. https://doi.org/10.1108/17538371011014017

Williams, T., Klakegg, O. J., Walker, D. H. T., Andersen, B., \& Magnussen, O. M. (2012). Identifying and acting on early warning signs in complex projects. Project Management Journal, 43(2), 37-53. https://doi.org/10.1002/pmj.21259

Zavadskas, E. K., Turskis, Z., \& Tamosaitiene, J. (2010), Risk assessment of construction projects. Journal of Civil Engineering and Management, 16(8), 33-46. https://doi.org/10.3846/jcem.2010.03 